* En esta sección «Debates» se recogen las ponencias, así como la relación conclusiva, del Seminario organizado por la Revista de Administración Pública y por la Sala Tercera del Tribunal Supremo, que se celebró el 7 de octubre de 2021 en Madrid. 



\title{
LA RUPTURA DEL EQUILIBRIO DEL CONTRATO Y SUS CORRECCIONES
}

\author{
ANTONIO JESÚS FONSECA-HERRERO RAIMUNDO \\ Magistrado de la Sala de lo Contencioso-Administrativo \\ del Tribunal Supremo
}

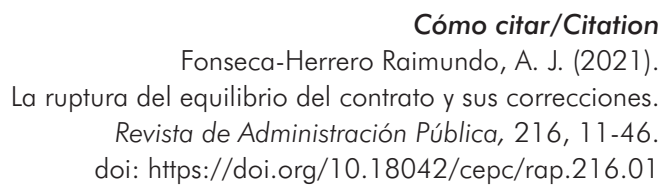

Resumen

Los presupuestos básicos de la contratación administrativa están orientados a la inalterabilidad de los contratos y a que su ejecución será a riesgo y ventura del contratista. Sin embargo, por unas u otras causas, se produce la ruptura del equilibrio inicial. Con apoyo en la jurisprudencia más representativa se hace una exposición de las técnicas de reequilibrio y de las soluciones alcanzadas, siempre asentadas en las particularidades del caso.

\section{Palabras clave}

Contratos administrativos; equilibrio económico; inalterabilidad; riesgo y ventura; equivalente económico; ius variandi; factum principis; fuerza mayor; riesgo imprevisible; riesgo operacional; COVID-19.

\section{Abstract}

The basic budgets of the administrative contracting are oriented to the inalterability of the contracts and to the fact that their execution will be at the risk and luck of the contractor. However, for one reason or another, the initial equilibrium is 
broken. With the support of the most representative jurisprudence, an exposition of the rebalancing techniques and the solutions reached is made, always based on the particularities of the case.

\section{Keywords}

Administrative contracts; economic equilibrium; inalterability; risk and luck; economic equivalent; ius variandi; factum principis; overwhelming force; unforeseeable risk; operating risk; covid-19. 


\section{SUMARIO}

I. EL REEQUILIBRIO ECONÓMICO FINANCIERO DEL CONTRATO: 1. Planteamiento. 2. Revisión de previos como mecanismo ordinario. 3. Técnicas tradicionales de garantía del equilibrio: 3.1. Ius variandi. 3.2. Factum principis. 3.3. Fuerza mayor. 3.4. Riesgo imprevisible. 4. Medidas para el reequilibrio económico del contrato. 5. Plazo de prescripción de la acción de reclamación. II. EQUILIBRIO ECONÓMICO Y RIESGO OPERACIONAL. III. COVID Y REEQUILIBRIO ECONÓMICO DEL CONTRATO. BIBLIOGRAFÍA.

\section{EL REEQUILIBRIO ECONÓMICO FINANCIERO DEL CONTRATO}

\section{PLANTEAMIENTO}

Para el análisis de esta cuestión considero necesario partir de la perfecta síntesis que, sobre los aspectos básicos de los contratos administrativos, contiene la STS de 6 de noviembre de 2015, recurso de casación 2785/2014 (ROJ: STS 5401/2015 - ECLI:ES:TS:2015:5401) cuando nos dice:

La primera es que el principio de la eficacia vinculante del contrato y de la invariabilidad de sus cláusulas es la norma general que rige en nuestro ordenamiento jurídico tanto para la contratación privada como para la contratación administrativa.

La segunda es que la contratación administrativa se caracteriza también por llevar inherente un elemento de aleatoriedad de los resultados económicos del contrato, al estar expresamente proclamado por la ley el principio de riesgo y ventura del contratista. Un elemento de aleatoriedad que significa que la frustración de las expectativas económicas que el contratista tuvo en consideración para consentir el contrato no le libera de cumplir lo estrictamente pactado ni, consiguientemente, le faculta para apartarse del vínculo contractual o para reclamar su modificación.

La tercera es que en nuestro ordenamiento jurídico ha sido tradicional establecer unas tasadas excepciones a esa aleatoriedad de los contratos administrativos, consistentes en reequilibrar la ecuación financiera del contrato únicamente cuando se ha producido una ruptura de la misma por causas imputables a la Administración ( «ius variandi» $\mathrm{o}$ «factum principis»), o por hechos que se consideran «extra muros» 
del normal «alea» del contrato por ser reconducibles a los conceptos de fuerza mayor o riesgo imprevisible. Lo cual significa que no toda alteración del equilibrio de las prestaciones del contrato da derecho al contratista a reclamar medidas dirigidas a restablecer la inicial ecuación financiera del vínculo, sino únicamente aquellas que sean reconducibles a esos tasados supuestos de «ius variandi», "factum principis», y fuerza mayor o riesgo imprevisible.

Tres principios esenciales pueden extraerse de esta síntesis: el de invariabilidad, el de riesgo y ventura, y el de equivalente económico. Los tres tienen apoyo en preceptos concretos de la vigente Ley 9/2017, de 8 de noviembre, de Contratos del Sector Público, por la que se transponen al ordenamiento jurídico español las Directivas del Parlamento Europeo y del Consejo 2014/23/UE y 2014/24/UE, de 26 de febrero de 2014 (en adelante, LCSP).

1. A la invariabilidad alude el art. 189 de la LCSP cuando dispone que: «Los contratos deberán cumplirse a tenor de sus cláusulas, sin perjuicio de las prerrogativas establecidas por la legislación en favor de las Administraciones Públicas». Y esta manifestación general del principio de invariabilidad aparece particularizada en el contrato de obras (art. 238), en las concesiones de obras (art. 252.1) y de servicios (art. 287), en el contrato de suministro (art. 300.1) y en el contrato de servicios (art. 311).

Como afirma Santiago Muñoz Machado:

La invariabilidad del contrato es una exigencia impuesta con carácter general también en la contratación civil, pero en los contratos administrativos tiene una razón añadida: la Administración no tiene más capacidad de disposición para gastar que la que le atribuyen en cada caso los presupuestos anuales; en ellos se fijan cantidades concretas para la contratación, cuya variación no puede dejarse ni a la discrecionalidad de la Administración ni al albur de lo que ocurra a lo largo de la vida de los contratos que celebra. Desde el principio, los órganos administrativos tienen que saber a qué se comprometen, sin que puedan asumir riesgos que no tengan cobertura en las previsiones presupuestarias generales.

2. Al riesgo imprevisible, inspirador de toda la ejecución de los contratos públicos, se refiere el art. 197 de la LCSP al establecer que: «La ejecución del contrato se realizará a riesgo y ventura del contratista, sin perjuicio de lo establecido para el contrato de obras en el artículo 239».

Siguiendo al mismo autor:

[...] tanto en la contratación civil como en la administrativa, la idea de la inmutabilidad del contrato la expresa el principio de riesgo y ventura, aplicado inicialmente a los contratos de obras, pero extendido luego a todas las demás: supone que el contratista se obliga a entregar una obra terminada y asumir las consecuencias y vicisitudes que pueden producirse antes de que la obra sea entregada definitivamente; los dańos que se puedan ocasionar a la obra o los perjuicios que circuns- 
tancias sobrevenidas puedan irrogar al contratista serán de su cuenta y tendrá que asumirlos necesariamente.

El principio de riesgo y ventura es así una expresión del carácter inmutable del contrato y representa un elemento de aleatoriedad de sus resultados económicos que, de acuerdo con la referida STS de 28 de octubre de 2015 (casación núm. 2785/2014), «significa que la frustración de las expectativas económicas que el contratista tuvo en consideración para consentir el contrato no le libera de cumplir lo estrictamente pactado ni, consiguientemente, le faculta para apartarse del vínculo contractual o para reclamar su modificación».

3. Al equivalente económico del contrato, que está regulado en la LCSP con un carácter bidireccional, pues es tanto un derecho del concesionario (art. 257.b) como una potestad administrativa (art. 262.1), se dedica el art. 270 cuando dispone que: «1. El contrato de concesión de obras deberá mantener su equilibrio económico en los términos que fueron considerados para su adjudicación, teniendo en cuenta el interés general y el interés del concesionario».

Como nos dice Gaspar Ariño Ortiz:

El principio del equivalente económico viene a ser así como el contrapunto necesario, en el orden financiero, a una situación de flexibilidad contractual en el objeto y contenido de las prestaciones. Con él se afirma la inmutabilidad a lo largo de la vida del contrato del equilibrio económico inicial, lo cual se conseguirá precisamente mediante el pago del equivalente económico necesario para restablecerlo cuando aquél se haya visto alterado.

Se trata de un principio que tiene carácter excepcional frente a la regla general del riesgo y ventura, de modo que para decidir sobre su procedencia habrá que analizar si la ruptura de equilibrio se debe a circunstancias y alteraciones económicas extraordinarias que, además de quedar claramente probadas, afectan a la economía del contrato por hacerlo excesivamente oneroso para el contratista y poniendo en riesgo la prestación del servicio, sin que sean imputables directa o indirectamente a la Administración. Así lo viene a precisar la STS con la dictada el 28 de enero de 2015 en el recurso de casación 449/2012 (ROJ: STS 956/2015 - ECLI:ES:TS:2015:956), cuando indican que «más allá de los supuestos tasados en la regulación general de la contratación pública, el reequilibrio sólo procederá cuando lo haya previsto el propio contrato y cuando una ley especial regule hipótesis específicas de alteración de la economía inicial del contrato y establezca medidas singulares para restablecerla».

Junto a estos tres principios de la contratación debe aludirse, por su carácter esencial y básico, al principio de libertad de pacto que consagra el art. 34 de la LCSP «en los contratos del sector público podrán incluirse cualesquiera pactos, cláusulas y condiciones», y a los límites que la propia LCSP la impone cuando (i) el art. 34 dice «siempre que no sean contrarios al interés público, al ordenamiento jurídico y a los principios de buena administración»; (ii) el art. 35 impone 
un contendido mínimo y sujeto a los pliegos de la contratación; (iii) el art. 189, después de regular el carácter vinculante de los contratos, dispone que lo es «sin perjuicio de las prerrogativas establecidas por la legislación en favor de las Administraciones Públicas».

Por último, es de advertir que «no existirá derecho al restablecimiento del equilibrio económico financiero por incumplimiento de las previsiones de la demanda recogidas en el estudio de la Administración o en el estudio que haya podido realizar el concesionario", tal y como precisan los arts. 270.2 y 290.4 LCSP.

\section{LA REVISIÓN DE PRECIOS COMO MECANISMO ORDINARIO}

La LCSP, después de establecer en su art. 102 que «los contratos del sector público tendrán siempre un precio cierto, que se abonará al contratista en función de la prestación realmente ejecutada y de acuerdo con lo pactado", y que es la máxima expresión del carácter oneroso del contrato que consagra el art. 2 de la propia ley, dispone que: «Los precios fijados en los contratos del sector público podrán ser revisados en los términos previstos en el Capítulo II de este Título, cuando deban ser ajustados, al alza o a la baja, para tener en cuenta las variaciones económicas de costes que acaezcan durante la ejecución del contrato».

Esta es la forma habitual de garantizar el mantenimiento del equilibrio económico de los contratos administrativos y tal mecanismo está actualmente contemplado y delimitado en los arts. 103 a 105 de la LCSP. Esta fórmula permite una adecuación del precio fijo del contrato a las variaciones que sufran elementos tomados en consideración por el contratista para presentar su oferta.

La STS de 4 de marzo de 2020, dictada en recurso de casación 4796/2018 (ROJ: STS 719/2020 - ECLI:ES:TS:2020:719), alude de forma específica a este sistema o mecanismo estableciendo las siguientes reglas básicas:

(i) que la revisión de precios integra un supuesto específico o especial de la modificación contractual que afecta a uno de sus elementos esenciales, cual es el precio o contraprestación económica que recibe el contratista por la ejecución o cumplimiento del contrato, y que tiene un régimen jurídico propio diferente al de los supuestos típicos de modificación contractual;

(ii) que el objetivo teórico de la revisión de precios es actualizar los precios ofertados por el contratista al momento de la adjudicación a los precios de mercado que se alcanzan en un momento posterior y durante la ejecución del contrato;

(iii) que la revisión de precios tiene un carácter restrictivo pues como indicara la sentencia de esta Sala Tercera de 13 de septiembre de 2012 (ROJ: STS 5940/2012 - ECLI:ES:TS:2012:5940), dictada en el recurso de casación 2105/2008, «la revisión de precios, como excepción al principio de riesgo y ventura, únicamente procederá en la forma y los casos previstos en los artículos 103 y siguientes del TR de la Ley de Contratos. No basta al respecto con invocaciones generales a la revisión o con genéricas alusiones a su traducción resarcitoria, sino que ha de estarse al régimen jurídico previsto en la Ley y a las cláusulas del contrato. Así, el apartado 3 del citado artículo 103 dispone que el pliego de cláusulas administrativas particulares 
deberá detallar la fórmula o sistema de revisión aplicable y, en resolución motivada, podrá establecerse la improcedencia de la misma que igualmente deberá hacerse constar en dicho pliego".

(iv) que también se ha afirmado por la jurisprudencia, sentencia de esta Sala Tercera de 8 de octubre de 2014 (ROJ: STS 4018/2014 - ECLI:ES:TS:2014:4018), dictada en el recurso de casación 2881/2013, que «el art. 14 TRLCAP estatuye que los órganos de contratación cuidarán de que el precio de los contratos sea adecuado al mercado. Por ello se fijan mecanismos legales para garantizar la equivalencia de prestaciones y el equilibrio financiero. Uno de tales mecanismos es la revisión de precios cuya fórmula o sistema de revisión deberá venir detallado en el pliego de cláusulas administrativas conforme al art. 104 TRLCAP, art. 103 TRLCAP, art. 77 de La ley 30/2007, de 30 de octubre, de Contratos del Sector Público, art. 89 y siguientes TR Ley Contratos del Sector Público, RD Legislativo 3/2011».

De otro lado, es importante destacar que la jurisprudencia ha admitido la compatibilidad de este mecanismo con las técnicas del reequilibrio económico. Así, la STS de 19 de enero de 1999, dictada en recurso de casación 1290/1990 (ROJ: STS 160/1998 - ECLI:ES:TS:1998:160), nos dice que:

Hay supuestos en que la técnica de la revisión de precios deviene ineficaz para lograr el adecuado equilibrio financiero del contrato por concurrir hechos que escapan a las previsiones ordinarias, produciendo un desequilibrio económico de tal entidad y naturaleza que el cumplimiento de las obligaciones por parte del contratista resulta excesivamente oneroso para él por tratarse de contingencias que razonablemente no pudieron preverse. Y en tales casos resulta de aplicación la teoría del riesgo imprevisible como medio extraordinario, y que constituye una excepción a la doctrina del riesgo y ventura del contratista, para restablecer el equilibrio financiero del contrato, actuando como fórmula compensatoria de los perjuicios ocasionados y que no han podido ser cubiertos por el mecanismo de la revisión de precios.

En este orden de cosas, cuando el art. 103 de la LCSP regula la procedencia y límites de la revisión de precios, nos dice que: «10. Lo establecido en este artículo y en la Ley 2/2015, de 30 de marzo, de desindexación de la economía española, se entenderá, en todo caso, sin perjuicio de la posibilidad de mantener el equilibrio económico en las circunstancias previstas en los artículos 270 y 290».

Es de apreciar que en la regulación actual la revisión de precios tiene importantes límites, ya que según el art. 103 de la LCSP, (i) «solo se podrá llevar a cabo en los contratos de obra, en los contratos de suministros de fabricación de armamento y equipamiento de las Administraciones Públicas, en los contratos de suministro de energía y en aquellos otros contratos en los que el período de recuperación de la inversión sea igual o superior a cinco años»; (ii) solo procederá la revisión "previa justificación en el expediente de contratación»; (iii) «salvo en los contratos de suministro de energía, solo podrá aplicarse la revisión cuando se haya ejecutado al menos el 20 por ciento del importe del contrato y cuando hayan transcurrido al menos dos años desde la formalización del mismo salvo en las con- 
cesiones de servicios para las que solamente se requerirá el requisito del tiempo»; (iv) «no serán revisables en ningún caso los costes asociados a las amortizaciones, los costes financieros, los gastos generales o de estructura, ni el beneficio industrial»; (v) «la revisión, cuando proceda, deberá ser periódica y predeterminada».

Por último, creo conveniente resaltar que la delimitación concreta de la técnica de la revisión de precios como garantía del mantenimiento del equilibrio económico del contrato exige tener presente un dato esencial y referido al hecho de que no permite afrontar todo riesgo que afecte a la economía del contrato, sino a la variación de precio por inflación, razón por la que se trata de afrontar un riesgo en algún modo previsto y ordenado en el contrato (a modo de medida preventiva) y no indefinido, general o abstracto, que es el que caracteriza el principio de riesgo y ventura.

\section{TÉCNICAS TRADICIONALES DE GARANTÍA DEL EQUILIBRIO}

Como ha quedado expuesto con la cita de la STS de 6 de noviembre de 2015, recurso de casación 2785/2014 (ROJ: STS 5401/2015 - ECLI:ES:TS:2015:5401), «no toda alteración del equilibrio de las prestaciones del contrato da derecho al contratista a reclamar medidas dirigidas a restablecer la inicial ecuación financiera del vínculo, sino únicamente aquéllas que sean reconducibles a esos tasados supuestos de «ius variandi», "factum principis», y fuerza mayor o riesgo imprevisible». Veamos cada una de ellas.

\subsection{Ius variandi}

Después de que el art. 189 de la LCSP condicione el carácter vinculante de los contratos a las prerrogativas establecidas por la legislación en favor de las Administraciones públicas, el art. 190 de la LCSP la enumera, incluyendo entre ellas la potestad de modificación, que es aquella que le permite variar el contenido del contrato por razones de interés público debido a necesidades nuevas o causas imprevistas. Con ello se viene a trasladar al ámbito de la contratación la prerrogativa de decisión unilateral ejecutiva general de los actos administrativos - arts. 38 y 39 de la Ley 39/2015, de 1 de octubre, del Procedimiento Administrativo Común de las Administraciones Públicas-.

La STS de 19 de febrero de 2020 (ROJ: STS 491/2020 - ECLI:ES: TS:2020:491), en recurso 626/2017, recoge la siguiente doctrina:

No puede caber duda alguna sobre existencia del privilegio de modificación unilateral de las concesiones ya que es reconocido por una reiterada doctrina de esta Sala Tercera. Así, cabe acudir a la sentencia de 12 de diciembre de 2019 (ROJ: STS 3974/2019) dictada en el recurso de casación 1558/201. La STS de 1 de febrero de 2000 (RC 645/1997) nos enseña que «La doctrina científica ha defendido, entre los privilegios de la Administración contratante, la potestad de modificar el contrato — “ius variandi”- , cuando así lo exija el interés público, cuyas exigencias, al servi- 
cio de la comunidad, no pueden quedar constreñidas por las cláusulas del contrato. De esta forma, un error inicial de la Administración contratante posteriormente detectado, o un cambio de las circunstancias tenidas en cuenta en el momento de contratar, o la adopción de medidas generales que, aunque no varíen directamente el objeto del contrato, inciden sobre él, permiten la posterior modificación del contrato para adaptarlo a las nuevas exigencias».

Esta potestad de modificación unilateral está desarrolla en el art. 203 de la LCSP: «[...] los contratos administrativos solo podrán ser modificados por razones de interés público en los casos y en la forma previstos en esta Subsección, y de acuerdo con el procedimiento regulado en el artículo 191, con las particularidades previstas en el artículo 207». Además, la LCSP contiene previsiones específicas sobre modificación en los diversos tipos de contratos administrativos: el art. 242 para el contrato de obras; el 255 para la concesión de obras; el 290 para la concesión de servicios; y el 319 para los contratos de los poderes adjudicadores que no tengan la condición de Administraciones públicas.

Hoy día debe considerarse estrechamente vinculada a principios básicos como la libertad de establecimiento, la libre competencia, la igualdad de trato y la no discriminación, y los principios de proporcionalidad y transparencia, hoy consagrados en los arts. 1, 64, 70, 132, 134, 154 de la LCSP.

La finalidad de esta potestad resulta clara a nivel doctrinal y jurisprudencial. La jurisprudencia de esta Sala, en sentencias reiteradas (SS de 13 de noviembre de 1978, 2 de julio de 1979, 9 de abril de 1985, 13 de julio de 1992, 29 de junio de 1995, 12 de julio de 1995), indica que "constituye un poder para adaptar los contratos a las necesidades públicas», que «el interés general es el que debe prevalecer en todo caso», que «la prevalencia del fin sobre el objeto [...] es la que justifica la habilitación a la Administración con una potestad de promover adaptaciones del objeto pactado para así conseguir tal fin».

Con base en estos preceptos cabe afirmar que el legislador sienta una regla general de prohibición de modificación y contempla la excepción de la modificación, sometiéndola a unos requisitos formales y sustantivos que evitan su posible utilización a mera conveniencia por parte de la Administración. Además, el art. 203 LCSP añade a ello que:

[...] en cualesquiera otros supuestos, si fuese necesario que un contrato en vigor se ejecutase en forma distinta a la pactada, deberá procederse a su resolución y a la celebración de otro bajo las condiciones pertinentes, en su caso previa convocatoria y sustanciación de una nueva licitación pública de conformidad con lo establecido en esta Ley, sin perjuicio de lo dispuesto en el apartado 6 del artículo 213 respecto de la obligación del contratista de adoptar medidas que resulten necesarias por razones de seguridad, servicio público o posible ruina.

La modificación contractual está sujeta a límites formales (de procedimiento ex art. 203.1 LCSP, en relación con los 199 y 207, y art. 203.3, en relación con 
los arts. 63, 153 y 207) y sustantivos puesto que «solo podrá llevarse a cabo durante la vigencia del contrato" y cuando concurran alguno de los supuestos que contempla el art. 203.2 «a) Cuando así se haya previsto en el pliego de cláusulas administrativas particulares, en los términos y condiciones establecidos en el artículo 204; b) Excepcionalmente, cuando sea necesario realizar una modificación que no esté prevista en el pliego de cláusulas administrativas particulares, siempre y cuando se cumplan las condiciones que establece el artículo 205».

La idea básica, tanto en los supuestos de modificaciones previstas como en las no previstas en los pliegos, es que las modificaciones no podrán afectar a las condiciones esenciales del contrato.

Así, respecto del primer supuesto — previsión en clausulado—, el art. 204 dispone que: «2. En ningún caso los órganos de contratación podrán prever en el pliego de cláusulas administrativas particulares modificaciones que puedan alterar la naturaleza global del contrato inicial». Además, la LCSP estipula cuándo se está ante esa alteración, pues a continuación nos dice que:

En todo caso, se entenderá que se altera ésta si se sustituyen las obras, los suministros o los servicios que se van a adquirir por otros diferentes o se modifica el tipo de contrato. No se entenderá que se altera la naturaleza global del contrato cuando se sustituya alguna unidad de obra, suministro o servicio puntual.

Junto a este límite cualitativo, el precepto fija uno cuantitativo, que será de aplicación en los supuestos en que la modificación no altere la economía global. Efectivamente, establece que: «1. Los contratos de las Administraciones Públicas podrán modificarse durante su vigencia hasta un máximo del veinte por ciento del precio inicial cuando en los pliegos de cláusulas administrativas particulares se hubiere advertido expresamente de esta posibilidad». Además, esta facultad de modificación queda sujeta a presupuestos formales - la cláusula de modificación deberá ser clara, precisa e inequívoca- y de contenido - la cláusula deberá precisar con el detalle suficiente su alcance, límites y naturaleza, las condiciones y el procedimiento-.

De otro lado, respecto de las no previstas en los pliegos, el art. 205.1 contempla la posibilidad de modificación si concurren dos requisitos: $1^{\circ}$ ) que se limite a introducir las variaciones estrictamente indispensables para responder a la causa objetiva que la haga necesaria: $2^{\circ}$ ) que encuentre su justificación en alguno de los supuestos que se relacionan en el art. 205.2 y que vienen referidos a la necesidad de ampliar el objeto del contrato, a la concurrencia de circunstancias sobrevenidas e imprevisibles y, finalmente, a que las modificaciones no sean sustanciales. En este último caso, la LCSP, además de indicar que una modificación se considerará sustancial cuando se cumpla una o varias de las condiciones que enumera y que están referidos a la selección del contratista, al equilibrio económico y al ámbito del contrato, impone la obligación de «justificar especialmente la necesidad de las mismas, indicando las razones por las que esas prestaciones no se incluyeron en el contrato inicial». 
El Tribunal Supremo ha tenido que afrontar la utilización de esta prerrogativa en numerosas sentencias referidas a todo tipo de supuestos que abarcan los relativos a modificaciones abusivas, nuevas prestaciones, diferencia entre modificaciones y prestaciones complementarias, modificaciones irregulares por razones formales o sustantivas, relación de la modificación con enriquecimiento injusto, etc. La imposible cita de todas ellas me lleva a la mención de las que, entre las más recientes, considero más relevantes. Veamos alguna de ellas:

\section{A) STSde19defebrerode2020(ROJ:STS491/2020-ECLI:ES:TS:2020:491) Recurso: 626/2017}

La sentencia parte de reconocer tanto la existencia y vigencia del privilegio de modificación unilateral de las concesiones sobre la base de una reiterada doctrina de la propia Sala Tercera como el principio de que las modificaciones acordadas por el órgano de contratación serán obligatorias para los contratistas.

Pero, a continuación, precisa que cosa diferente es que concurran los presupuestos habilitantes para el ejercicio del ius variandi, cuestión que analiza partiendo del primer motivo de nulidad invocado por la concesionaria: que la modificación unilateral de la concesión ha incidido, indebidamente, sobre uno de los elementos esenciales del contrato concesional, sobre la contraprestación, que no es otra que el peaje por sistema de tarifa.

Tal cuestión es analizada en su FD octavo:

[...] el régimen jurídico de la concesión permite hacer alguna precisión pues el ejercicio de esa facultad o potestad, que comporta un elemento de discrecionalidad, además de estar sujeto a un determinado procedimiento, está delimitado por factores sujetos a control, cuales son, que su ejercicio se justifique por razones de interés público, y que la modificación no conlleve o produzca la alteración de las condiciones esenciales de la licitación y adjudicación, debiendo limitarse a introducir las variaciones estrictamente indispensables para responder a la causa objetiva que la haga necesaria.

Es evidente, además, que la modificación deberá (1) responder a necesidades nuevas o causas imprevistas, pues lo contrario vulneraría el principio esencial de riesgo y ventura regulado en el artículo 242 del Real Decreto Legislativo 3/2011, de 14 de noviembre, por el que se aprueba el texto refundido de la Ley de Contratos del Sector Público, y (2) buscar el restablecimiento del régimen económico financiero de la concesión, regulado como derecho básico del concesionario -ex artículo $245, \mathrm{~b}$ ) de esa misma norma- y como potestad de la administración —ex artículo 249.1,c)—, finalidad que viene impuesta por el artículo 24.dos de la Ley 8/1972.

Pues bien, con base en estas previsiones normativas, consideramos que esta regulación impide la variación del régimen de retribución del contratista cuando se 
alteren las bases para la determinación de ese régimen retributivo sin incidir en la cuantía de las tarifas y, por tanto, se haga depender la retribución compensatoria de elementos extrańos al sistema inicialmente determinado, que era el tarifario, y ello con independencia de quien abone las tarifas por el uso del servicio, es decir, se establezca el pago directo por los usuarios o el pago a la sombra por la administración. En todo caso, no se cuestiona en este recurso ese cambio de peaje al sol a peaje a la sombra.

B) STS de 30 de octubre de 2019 (ROJ: STS 3484/2019 - ECLI:ES: TS:2019:3484)

Recurso: $2717 / 201$

En auto de admisión de 5 de diciembre de 2017 se fijó la siguiente cuestión de interés casacional fijada:

Si la revisión de las condiciones económicas de los conciertos sanitarios, por aplicación del artículo 90.4 de la Ley General de Sanidad, es una facultad que puede ejercer libremente la Administración o si, por el contrario, constituye una modificación unilateral que, en la medida en que afecta al régimen financiero del contrato, ha de acomodarse a la legislación de contratos.

La sentencia concluyó que:

[...] la actualización de las condiciones económicas efectuada por la resolución 146/2014, en aplicación de la Orden de 13 de febrero de 2014, a su vez dictada conforme al artículo 90.4 de la Ley 14/1986, supone una modificación unilateral del contrato que afecta a su régimen financiero y ha de acomodarse a la legislación de contratos del sector público.

Parte para ello de dos consideraciones: (i) el hecho de que las cláusulas del Pliego de las Particulares, si bien incluyen a la Ley 14/1986 entre las disposiciones por las que se regirá el contrato, no precisa que este se someterá a la actualización discutida y no permite considerar que existe una aceptación previa por el contratista de la posibilidad de que los precios se rebajen sin ninguna compensación en el curso de su cumplimiento; (ii) rebajar los precios de un contrato que se está cumpliendo al margen del procedimiento para revisarlos contenido en el Pliego por el que se rige no puede no verse como una modificación impuesta por la Administración; (iii) en ningún momento la Administración acreditó que los nuevos precios respondan a los costes reales del servicio y que no afectaban al concreto equilibrio del contrato, mientras que la oferta de la contratista tuvo en cuenta las condiciones económicas prefijadas por la propia Junta de Andalucía en el momento de la licitación y con arreglo a ellas se estableció el régimen económico del contrato. 


\subsection{Factum principis}

La STS 29 de mayo de 2007, dictada en el recurso de casación 8202/2004 (ROJ: STS 4079/2007-ECLI:ES:TS:2007:4079), nos dice que:

[...] el principio "factum príncipis» se asocia, [...] a aquellos supuestos en que la adopción por la Administración de medidas de carácter económico o social, acordadas al margen del contrato, tienen una repercusión negativa en su ejecución por hacerlo más oneroso para una de las partes, causando perjuicios concretos para el contratista o el concesionario, determina el reconocimiento judicial de la obligación de la Administración, con base a razones de equidad, con independencia de la aplicación del procedimiento contractual de revisión de precios o tarifas, de mantener indemne el equilibrio de las prestaciones económicas, compensando o indemnizando por los daños y perjuicios ocasionados.

El llamado factum principis o «hecho del príncipe» se produce por una actuación de la Administración, derivada de una decisión voluntaria adoptada al margen y con total independencia de la relación contractual, pero que, aunque no lo persigue, altera indirectamente las condiciones de ejecución del contrato haciéndolo más gravoso para el contratista, que nunca pudo preverlas o tenerlas en cuenta, y que, por tanto, produce una alteración del equilibrio económico del contrato.

Esta misma sentencia diferencia el «factum principis» del «ius variandi», afirmando que:

La modificación de uno de los elementos del contrato concesional no deriva del ejercicio de las prerrogativas o derechos reconocidos a la Administración concedente por la legislación de contratos del Estado, sino de la voluntad del Gobierno que se concretiza mediante la aprobación de una norma con fuerza de Ley, y, en consecuencia, no se adopta en virtud de la potestad de modificar las condiciones de prestación de la concesión por razones de interés público vinculadas a la gestión de este servicio público, ni se somete al procedimiento previsto para garantizar el ejercicio ponderado de esta prerrogativa.

Su regulación más precisa se encuentra actualmente en los arts. 270.2 y 290.4 LCSP cuando disponen que: «Se deberá restablecer el equilibrio económico del contrato, en beneficio de la parte que corresponda, en los siguientes supuestos: b) Cuando actuaciones de la Administración Pública concedente, por su carácter obligatorio para el concesionario, determinaran de forma directa la ruptura sustancial de la economía del contrato». En estos supuestos se contempla expresamente el derecho al reequilibrio a través de los mecanismos que enumera el art. 270.3; por tanto, mediante la adopción de las medidas que en cada caso procedan y que podrán consistir en alguna de las que enumera, cuestión a la que más delante me referiré. 
La STS de 16 de mayo de 2011, dictada en recurso 566/2008 (ROJ: STS 3125/2011 - ECLI:ES:TS:2011:3125), referida a un contrato de concesión de obra pública para la construcción, conservación y explotación de la autopista de peaje Madrid-Toledo AP-41 y la autovía libre de peaje A-40 de Castilla-La Mancha, tramo circunvalación Norte de Toledo, analiza la influencia que pudieran tener sobre el equilibrio financiero de la concesión administrativa la no ejecución por parte de la Administración concedente de otras obras de infraestructura necesarias para la viabilidad de la propia concesión administrativa.

Se trataba de la construcción de una nueva autopista desde Toledo a Córdoba, pasando por Ciudad Real, incluida en el Plan Estratégico de Infraestructuras del Transporte 2000-2007, presentado por el ministro de Fomento en 2000, y que no se llevó a cabo tras la resolución dictada por Secretaría General para la Prevención de la Contaminación y el Cambio Climático, en trámite de la declaración de impacto ambiental, que destacaba que:

[...] dicho proyecto es incompatible con el medio ambiente, sobre el que previsiblemente causaría efectos negativos significativos; que las afecciones a los lugares de la Red Natura 2000 serían significativas, entrando en contradicción con los objetivos de conservación, y en consecuencia con el mantenimiento de la coherencia de la Red Natura 2000; y que las medidas previstas por el Promotor no son una garantía suficiente de la completa corrección o adecuada compensación de la Red Natura 2000.

La sentencia reconoce el derecho al reequilibrio económico de un contrato de concesión de obras públicas por la falta de realización de una obra prevista en el Plan de Infraestructuras y Transporte. Entiende la Sala que la entrada en servicio de la nueva autopista desde Toledo a Córdoba tenía un peso fundamental en el planteamiento de la AP-41, pues que aquella fue concebida como la primera parte del nuevo acceso a y desde Andalucía. Por tanto, siendo este un presupuesto esencial en la concepción de la AP-41, «su ausencia ha de afectar decisivamente al equilibrio económico y financiero", pues, concluyó la STS, «el proyecto del que hablamos era, en el momento de presentación de las ofertas para la adjudicación de la AP-41, algo más que un evento hipotético y futuro, que es la condición que le atribuye la segunda contestación a la demanda, y que su ausencia altera el equilibrio económico y financiero de la concesión por lo que procede su restablecimiento".

Deben analizarse en este ámbito varias cuestiones de evidente interés que tanto a nivel teórico como práctico se han venido planteado:

1a) Si las actuaciones de una Administración distinta a la concedente podrían integrar este supuesto de reequilibrio.

El Tribunal Supremo estimó la concurrencia del factum principis y el derecho del adjudicatario del servicio de ambulancia del INSALUD a ser resarcido cuando, como consecuencia del incremento del precio del combustible aprobado 
por el Ministerio de Hacienda, el equilibrio del contrato se rompió (SSTS de 20 de noviembre y 2 de diciembre de 1985, RJ 1985, 5566 y 6511, respectivamente). Sin embargo, pronunciamientos más recientes llegan a una solución diferente. En este sentido cabe citar varias sentencias:

a) La STS de 16 de mayo de 2011, dictada en recurso de casación 566/2008 (ROJ: STS 3125/2011 - ECLI:ES:TS:2011:3125), que trata la influencia que pudiera tener sobre el equilibrio financiero de una concesión administrativa (autopista de peaje Madrid-Toledo y la autovía libre de peaje A-40 de Castilla-La Mancha, tramo circunvalación Norte de Toledo) la construcción de infraestructuras por parte de otras Administraciones (la comunidad autónoma de Madrid acometía la mejora de esa carretera M-407, entonces de una sola calzada en cada dirección, para pasar a ser autovía).

La STS afirma que el desdoblamiento de la M-407 no parece que sea un hecho extraordinario e imprevisible que deba quedar fuera del riesgo y ventura del contratista, tomando en consideración: (i) que antes de la presentación de ofertas para la adjudicación de la concesión se había previsto esa mejora de esa carretera M-407; (ii) que en el Plan REDSUR de la Comunidad de Madrid presentado el 22 de enero de 2004 figura ya como autovía.

Con rotundidad se dice que una cosa es que la Administración concedente deba responder por lo que ya existe y es conocido en el momento de convocar el concurso, pues forma parte de la realidad en la que va a insertarse la concesión, y otra, bien distinta, que deba responder por decisiones posteriores de otros sujetos.

b) La STS de 19 de diciembre de 2019, dictada en recurso de casación 2390/2016 (ROJ: STS 4209/2019- ECLI:ES:TS:2019:4209), haciendo interpretación del art. 241 de la LCSP de 2007, contiene el siguiente razonamiento:

Es evidente que solo las actuaciones de la Administración contratante - y no las de otra- son las que pueden determinar la ruptura sustancial de la economía de la concesión. De forma muy explícita se expresa el precepto considerado como infringido que, en su apartado 1, efectivamente, impone la obligación del mantenimiento de su equilibrio económico, más tal mantenimiento o equilibrio ha de llevarse a cabo «en los términos que fueron considerados para su adjudicación», esto es, en los términos que fueron considerados para su adjudicación por la Administración que llevó a cabo la adjudicación y contratación —y no por otra-, pues, claro es, la intervención, actuación o no actuación de un tercero - aunque sea otra Administración — no puede incidir en el vínculo jurídico, bilateral y sinalagmático, que la concesión y el contrato implican. Y, mucho menos, tal intervención externa al citado vínculo jurídico puede ser determinante de una exigencia de mantenimiento del equilibrio por parte de una Administración que ha cumplido, estrictamente, con su vínculo bilateral pactado. 
A mayor abundamiento, el propio precepto —en su apartado 2.b), que se considerada infringido por la recurrente - requiere que las actuaciones de la Administración, que puedan dar lugar a una ruptura sustancial de la economía de la concesión, han de llevarse a cabo «de forma directa». De ello debe deducirse — de tal concreta expresión- que sólo la Administración implicada en la concesión es la que, «de forma directa», puede provocar la ruptura sustancial de la economía de la misma; la intervención de otras Administraciones, como se pretende, sólo sería una intervención indirecta, pero sin entidad para afectar al equilibrio del contrato; si bien se observa, el legislador ha contemplado, en el mismo artículo y apartado, otra causa de alteración del citado equilibrio, cual es la "fuerza mayor» pero, obviamente, en tal concepto no tienen cabida las actuaciones de otra Administración, y menos con los motivos por lo que aquí ha actuado la Administración del Estado.

El Consejo de Estado (Dictamen 1030/2015) ha entendido que los supuestos de ruptura de equilibrio por actuaciones de una Administración distinta de la concedente pueden reconducirse a la teoría del riesgo imprevisible, planteamiento que parece descansar en la idea de que las relaciones de colaboración entre Administración y contratista están inspiradas en los principios de lealtad institucional y buena fe.

2a) Si dentro de las actuaciones de la Administración concedente tienen cabida las decisiones por ella adoptadas en disposiciones generales.

Nada indican al respecto los arts. 270.2.b y 290.4.b. En tales casos podremos interpretar que estamos ante "actuaciones» de la Administración concedente y, por tanto, admitir el derecho a restablecimiento de equilibrio, o, por el contrario, que debemos equiparar estos casos a los previstos para "disposiciones generales» de otras Administraciones, con la consecuencia de que en esos casos estaríamos ante la posibilidad de desistimiento, como ahora veremos.

Esta segunda posibilidad quizá chocase con la premisa general de compensación por modificaciones para que se mantenga el equilibrio de los supuestos económicos que fueron considerados como básicos en la adjudicación del contrato y que se asienta en una interpretación pro mantenimiento de la relación contractual.

3a) Si una disposición general de una administración distinta a la concedente aprobada posterioridad a la formalización del contrato puede integrar un supuesto de factum principis.

Actualmente la LCSP (arts. 270.4.a y 290.6.a) contempla para estos casos la posibilidad de desistimiento del concesionario por excesiva onerosidad del contrato, sin derecho a indemnización alguna para ninguna de las partes. La ley delimita aquí, de manera expresa, el concepto de onerosidad refiriéndola a:

[...] cuando la incidencia de las disposiciones de las Administraciones o el importe de las mejoras técnicas que deban incorporarse supongan un incremento neto anualizado de los costes de, al menos, el 5 por ciento del importe neto de la cifra de negocios de la concesión por el período que reste hasta la conclusión de la 
misma. Para el cálculo del incremento se deducirán, en su caso, los posibles ingresos adicionales que la medida pudiera generar.

Por tanto, cuando el exceso de onerosidad del contrato deriva de una disposición general aprobada después de su formalización por una Administración distinta de la concedente, la LCSP no configura realmente una situación de reequilibrio económico, sino que está imponiendo la aplicabilidad del riesgo y ventura del contratista, reconociendo la posibilidad de desistimiento.

Esta misma consecuencia se regula en las denominadas «cláusulas de progreso", para los casos en que el concesionario deba incorporar a las obras o a su explotación, por venir obligado a ello legal o contractualmente, avances técnicos que las mejoren notoriamente y cuya disponibilidad en el mercado, de acuerdo con el estado de la técnica, se haya producido con posterioridad a la formalización del contrato. Sobre la aplicación de este tipo de cláusula por parte del Tribunal Supremo cabe citar la STS de 20 de diciembre de 1986 (ROJ: STS 7263/1986 - ECLI:ES:TS:1986:7263) al resolver sobre un supuesto de mantenimiento del equilibrio financiero en una concesión de servicio público de transporte urbano de La Coruña, afirmó que la sustitución de trolebuses por autobuses, impuesta por una norma técnica "debe considerarse como una aplicación concreta de la cláusula de progreso, implícita en las concesiones de servicios públicos y que obliga a que la prestación de éstos se desarrolle de acuerdo con los adelantos de la técnica».

4a) Al margen de la regulación legal, también es objeto de discusión si pueden ser incluidas en el factum principis las medidas de carácter legislativo (y no solo por decisiones administrativas o disposiciones de carácter reglamentario). A continuación, se hace cita de tres supuestos analizados por el Tribunal Supremo.

—La STS de 29 de mayo de 2007, dictada en recurso de casación 8202/2004 (ROJ: STS 4079/2007-ECLI:ES:TS:2007:4079), rechaza tal posibilidad afirmando que:

[...] deviene inaplicable cuando la Ley establece directamente un mecanismo de restablecimiento del equilibrio económico-financiero del contrato concesional, como acontece en este proceso, en que el artículo 8 del Real Decreto-Ley 6/1999 prevé la iniciación del procedimiento de revisión de los contratos de concesión de autopistas para rebajar las tarifas de peaje satisfechas por los usuarios en un 7 por ciento de su importe e impone a la Administración General del Estado la obligación de liquidar a las sociedades concesionarias de su ámbito competencial por la pérdida de ingresos que les suponga la bajada de tarifas, y de celebrar convenios de colaboración cuando la Administración concedente sea una Comunidad Autónoma.

—La STS de 16 de diciembre de 2013, dictada en recurso de casación 2882/2012 (ROJ: STS 6368/2013 - ECLI:ES:TS:2013:6368), analiza y rechaza los efectos que pudiera tener la fluctuación del tipo del IVA en la economía del contrato porque el precio del contrato administrativo incluye el IVA a todos los efectos. La Sala reconoce el derecho del concesionario de un hospital a percibir, 
en ejecución del contrato de concesión, la cantidad máxima anual ofertada en su día, sin perjuicio de las modificaciones que haya experimentado el tipo de gravamen correspondiente al IVA aplicable, de forma que la retribución pactada entre la Administración pública contratante y el contratista no puede modificarse, ni al alza ni a la baja, como consecuencia de las fluctuaciones del tipo de gravamen propio de este tributo. No es necesario restablecer el equilibrio económico del contrato, pues este no se ha roto, desde el momento en que la Administración no queda obligada a pagar más de aquello a lo que se había comprometido, incluido el IVA.

- Como última cita, decir que por ATS, de 6 de mayo de 2021, dictado en recurso de casación 7119/2019 (ROJ: ATS 5834/2021 - ECLI:ES: TS:2021:5834A), se admite un recurso de casación referido a un contrato de concesión para construcción y explotación de un aparcamiento subterráneo donde la mercantil recurrente planteaba si los concesionarios de aparcamientos subterráneos que tras la adjudicación del contrato concesional se ven sujetos al pago del IBI como consecuencia de la sobrevenida desaparición de la exención a resultas de la Ley 14/2000, tienen la posibilidad de instar el reequilibrio de la concesión ante un hecho que pueda calificarse de sobrevenido e imprevisible y que, en definitiva, se configura como excepción al principio general del riesgo y ventura. Como consecuencia de esta reforma del art. 64 de la LHL desaparece la exención de los bienes que sean propiedad de los municipios en que estén enclavados afectos al uso o servicio público, cuando sobre ellos o sobre el servicio público al que se hallen afectados recaiga una concesión administrativa u otra forma de gestión indirecta.

La cuestión que reviste interés casacional objetivo para la formación de jurisprudencia, a juicio de la Sala Tercera del Tribunal Supremo, es la determinación del significado y alcance de la doctrina del «factum principis» y sus efectos sobre la economía del contrato, y, en detalle, si la sobrevenida sujeción al pago del impuesto sobre bienes inmuebles por parte del concesionario comporta inexorablemente la ruptura del equilibrio económico-financiero del contrato o si, por el contrario, la desaparición de la exención al pago de dicho impuesto local, operada por norma con rango de ley, se inscribe en el principio de riesgo y ventura y no determina el nacimiento de derecho a compensación alguno a cargo de la Administración contratista. Y ello, atendiendo especialmente a la existencia de fallos contradictorios de distintas Salas territoriales en torno a la cuestión controvertida. Es evidente que, en este caso, estará en juego el riesgo y ventura y la cuestión del posible desistimiento.

\subsection{Fuerza mayor}

Ya ha quedado dicho que el principio de riesgo y ventura, que es uno de los centrales y básicos de la contratación administrativa, está regulado de forma general en el art. 197 de la LCSP. 
Pero como ya se ha anticipado, esta regla general admite como excepción los supuestos de fuerza mayor. Así, dentro de la ejecución del contrato de obras, el art. 239.1 de la LCSP dispone que:

En casos de fuerza mayor y siempre que no exista actuación imprudente por parte del contratista, este tendrá derecho a una indemnización por los daños y perjuicios, que se le hubieren producido en la ejecución del contrato.

En el contrato de concesión de obras, el art. 254, después de contemplar que las obras se ejecutarán a riesgo y ventura del concesionario, establece que:

2. Si la concurrencia de fuerza mayor implicase mayores costes para el concesionario se procederá a ajustar el plan económico-financiero. Si la fuerza mayor impidiera por completo la realización de las obras se procederá a resolver el contrato, debiendo abonar el órgano de contratación al concesionario el importe total de las ejecutadas, así como los mayores costes en que hubiese incurrido como consecuencia del endeudamiento con terceros.

Por tanto, solo en caso de incremento de costes y no en los de imposibilidad de ejecución estaremos ante un supuesto de reequilibrio económico del contrato. Ya en el ámbito de las concesiones administrativas, los arts. 270.2 y 290.4 de la LCSP, disponen que:

Fuera de los casos previstos en las letras anteriores, únicamente procederá el restablecimiento del equilibrio económico del contrato cuando causas de fuerza mayor determinaran de forma directa la ruptura sustancial de la economía del contrato. A estos efectos, se entenderá por causas de fuerza mayor las enumeradas en el artículo 239.

La configuración y alcance de la fuerza mayor han tenido clara precisión en la jurisprudencia del Tribunal Supremo. Así, la STS de 13 de febrero de 2018, en recurso de casación 2832/2015 (ROJ: STS 438/2018 - ECLI:ES:TS:2018:438), argumenta que:

Sin embargo la ley establece que este principio de riesgo y ventura tiene como excepción los supuestos de fuerza mayor, al constituir éstos, según destaca la STS de 15 de marzo de 2005, factores imprevisibles, anormales en el desarrollo propio de la naturaleza de las obras y ajenos a la voluntad y comportamiento del contratista, que inciden negativamente en la ejecución del contrato, suponiendo para el mismo un agravamiento sustancial de las condiciones, que por exceder de las contingencias propias del riesgo asumido en la contratación, se contemplan específicamente por la Ley a efectos de restablecer el equilibrio financiero del contrato, como principio sustancial en materia de contratación.

$\mathrm{Y}$ añade esta misma sentencia de 15 de marzo de 2005 que la concurrencia y aplicación congruente de tales principios, esenciales en la configuración de la contratación administrativa, justifican la determinación por la ley de las concretas causas de fuerza mayor que exoneran al contratista del riesgo asumido por el mismo, propiciando que sea indemnizado en tales casos por los dańos y perjuicios que se le 
hubieran ocasionado, enunciación de causas de fuerza mayor que la jurisprudencia viene considerando de carácter tasado y de interpretación restrictiva.

De esta y otras sentencias se extraen las siguientes características de la fuerza mayor: (i) imprevisibilidad, por derivar de factores o hechos imprevisibles que sean anormales en el desarrollo del contrato; (ii) inevitabilidad, por ser necesario que ellos fueran inevitables; (iii) ajenidad, por exigirse que sean ajenos a la voluntad y comportamiento del contratista: (iv) insoportabilidad, en cuanto que acarreen la ruptura sustancial de la economía del contrato.

En la línea de lo dicho, la STS de 13 de febrero de 2018 nos refiere — «[...] la determinación por la ley de las concretas causas de fuerza mayor»— hemos de decir que esas concretas causas, que por mor del art. 239.1 solo entrarán en juego «siempre que no exista actuación imprudente por parte del contratista», son las que, con carácter tasado, enumera el art. 239.2:

Tendrán la consideración de casos de fuerza mayor los siguientes: a) Los incendios causados por la electricidad atmosférica. b) Los fenómenos naturales de efectos catastróficos, como maremotos, terremotos, erupciones volcánicas, movimientos del terreno, temporales marítimos, inundaciones u otros semejantes. c) Los destrozos ocasionados violentamente en tiempo de guerra, robos tumultuosos o alteraciones graves del orden público.

El art. 239.2.b) contempla como supuesto de fuerza mayor los fenómenos naturales de efectos catastróficos y realiza una enumeración ejemplificativa cuando emplea la expresión "como», citando "maremotos, terremotos, erupciones volcánicas, movimientos del terreno, temporales marítimos, inundaciones», y cierra añadiendo «u otros semejantes». Únicamente haré dos menciones sobre esta regulación:

a) Que la STS de 17 de julio de 2018, dictada en recurso de casación 638/2017 (ROJ: STS 2872/2018 - ECLI:ES:TS:2018:2872), se ha considerado con fuerza mayor las lluvias excepcionales que, durante los días 22 a 25 de octubre de 2000, afectaron a distintos elementos e instalaciones de la autopista de peaje AP-7, tramo Tarragona-Alicante.

b) Que la expresión «u otros semejantes» plantea el problema de si la previsión de semejanza puede alcanzar a fenómenos naturales que puedan asimilarse a los supuestos enumerados y completamente a la intervención humana o es posible la interferencia de la acción humana. Sobre el particular solo debo decir que ha sido dictado auto de 22 de abril de 2021, dictado en recurso de casación 2809/2020 (ROJ: ATS 5087/2021 - ECLI:ES:TS:2021:5087A), admitiendo a trámite un recurso de casación en el que se plantea la siguiente cuestión de interés casacional: «[...] si el concepto de fuerza mayor del artículo 231 del texto refundido de la Ley de Contratos del Sector Público (actual artículo 239 de la Ley 9/2017), puede comprender aquellos fenó- 
menos medioambientales catastróficos, en los que tiene incidencia la acción humana». En este caso se plantea el examen de la relación entre la contaminación del Mar Menor y la consideración de fenómeno natural catastrófico constitutivo de fuerza mayor, teniendo en cuenta que existe intervención humana, partiendo de una solicitud de reequilibrio económico solicitado por la concesionaria de obras y servicios del puerto deportivo Mar de Cristal por la reducción drástica de la demanda del servicio portuario.

\subsection{Riesgo imprevisible}

La cláusula de riesgo imprevisible está expresamente contemplada en la Directiva 2014/24/UE del Parlamento Europeo y del Consejo, de 26 de febrero de 2014, sobre contratación pública, cuando su considerando 109 contempla que:

Los poderes adjudicadores pueden encontrarse con circunstancias ajenas que no podían prever cuando adjudicaron la concesión, en particular si la ejecución del contrato se extiende durante un largo período de tiempo. En este caso, hace falta cierto grado de flexibilidad para adaptar el contrato a esas circunstancias sin necesidad de un nuevo procedimiento de contratación.

El concepto de circunstancias imprevisibles hace referencia a aquellas circunstancias que no podrían haberse previsto aunque el poder adjudicador hubiera preparado con razonable diligencia la adjudicación inicial, teniendo en cuenta los medios a su disposición, la naturaleza y las características del proyecto concreto, las buenas prácticas en el ámbito de que se trate y la necesidad de garantizar una relación adecuada entre los recursos empleados en la preparación de la adjudicación y su valor previsible.

Sin embargo, la LCSP de 2017, por la que se traspone al ordenamiento jurídico español la Directiva del Parlamento Europeo y del Consejo 2014/24/UE, de 26 de febrero de 2014, siguiendo la línea de sus precedentes normativos, no contempla el riesgo imprevisible como causa de la ruptura del equilibrio económico, sino que las refiere a los supuestos hasta ahora analizados de "ius variandi», «factum principis» $\mathrm{y}$ «fuerza mayor».

Su formulación positiva en nuestra legislación administrativa se encuentra en el art. 127.2.b) del Decreto de 17 de junio de 1955, por el que se aprueba el Reglamento de Servicios de las Corporaciones locales, cuando dispone que:

2. La Corporación concedente deberá: $2 .^{\circ}$ Mantener el equilibrio financiero de la concesión, para lo cual: b) revisará las tarifas y subvención cuando, aun sin mediar modificaciones en el servicio, circunstancias sobrevenidas e imprevisibles determinaren, en cualquier sentido, la ruptura de la economía de la concesión.

Esta norma viene a identificar las circunstancias sobrevenidas e imprevisibles con aquellas que ocasionan una «subversión en la economía de la concesión». 
Así, cuando delimita las obligaciones del concesionario, le impone la de "prestar el servicio del modo dispuesto en la concesión u ordenado posteriormente por la Corporación concedente, incluso en el caso de que circunstancias sobrevenidas e imprevisibles ocasionaren" (128.1.1 a $^{\mathrm{a}}$.

Su aplicación como fuente de reequilibrio ha sido admitida y apreciada por la jurisprudencia, debiendo destacarse que se ha llevado a cabo con criterios restrictivos y, por ello, casuísticos, convirtiéndose en una categoría residual que ha dado cabida a todos los supuestos que escapaban de las denominadas causas legales. Lo contrario podría implicar la vulneración de las garantías del proceso de contratación derivadas de los principios de libre concurrencia, igualdad y transparencia.

La STS de 25 de abril de 2008, dictada en recurso de casación 5038/2006 (ROJ: STS 1809/2008 - ECLI:ES:TS:2008:1809), ha venido a conceptuar el riesgo imprevisible afirmando que:

Es indudable que la imprevisibilidad contempla sucesos que sobrevienen con carácter extraordinario que alteran de forma muy notable el equilibrio económico y contractual existente en el momento del contrato pues sobrepasan los límites razonables de aleatoriedad que comporta toda licitación. Implica, por tanto, aplicar los principios de equidad (art. 3.2 C. Civil ) y de buena fe (art. 7.1 C. Civil) por la aparición de un riesgo anormal que cercena el principio del equilibrio económico-financiero entre las partes pero sin atacar frontalmente el principio de riesgo y ventura esencial en la contratación pública.

Prueba del carácter restrictivo en su apreciación es la reciente STS de 9 de septiembre de 2020, dictada en recurso de casación 2394/2016 (ROJ: STS 2807/2020 - ECLI:ES:TS:2020:2807), donde se dice que:

El principio de riesgo y ventura no cede ante una alteración sobrevenida de las circunstancias sino cuando ésta (fuera de los supuestos de fuerza mayor) es de tal índole que comporta una quiebra radical del equilibrio económico financiero contractual, por su excesiva onerosidad, por su imposible compensación mediante la revisión de precios cuando así esté pactada — como aquí acontece, revisión que fue efectuada y asumida, sin protesta, por la hoy recurrente- y por suponer una frustración completa de los presupuestos contractuales (todo ello conjuntamente). Como ha mantenido el Consejo de Estado en sus dictámenes 953/2011, 954/2011, 65/2012, 1.334/2012 y 158/2013, entre otros, la doctrina de la cláusula "rebus sic stantibus», como límite a la aplicación del principio de riesgo y ventura, no puede trasladarse sin más a otra construcción jurídica, la de la excesiva onerosidad, aplicable a las prestaciones caracterizadas por la conmutatividad contractual.

Esa aplicación restrictiva del riesgo imprevisible es consecuencia de otra de las características de la configuración jurisprudencial del riesgo imprevisible consistente en que no puede llegar a entenderse como una garantía global del riesgo que alcance a la totalidad de los perjuicios que pueda padecer el contratista, en un 
seguro gratuito de riesgos contrario al principio central del riesgo y ventura. Así la STS de 28 de enero de 2015, dictada en recurso de casación 449/2012 (ROJ: STS 956/2015-ECLI:ES:TS:2015:956), afirma que la disminución de tráfico, acaecida desde el inicio mismo de la explotación, no resulta encuadrable en el riesgo imprevisible.

La cita de esta sentencia nos lleva a analizar una nueva cuestión, referida a si las crisis económicas se integran en el concepto de riesgo imprevisible y, por tanto, son causa de la ruptura del equilibrio económico del contrato, haciendo posible su modificación.

El criterio del Tribunal Supremo aparece fijado en esa sentencia de 28 de enero de 2015, que reitera lo dicho en STS de 4 de febrero de 2014, en recurso de casación 486/2011 (ROJ: STS 952/2014 - ECLI:ES:TS:2014:952), y que también se refiere en otras posteriores y más recientes, como la STS de 14 de febrero de 2020, recaída en recurso de casación 2947/2016 (ROJ: STS 440/2020 - ECLI:ES:TS:2020:440), cuando afirma que:

Es hecho notorio que las crisis económicas acontecidas en los siglos XX/XXI han sido cíclicas, así como que el desarrollo urbanístico no siempre progresa sino que, en ocasiones, se paraliza. No constituye, pues, una realidad inesperada, aunque pueda desconocerse el momento exacto de producción.

Actualmente llevamos ańos en crisis económica, pero en época no muy lejana, década de los 1990 hubo otra crisis económica mundial que también afectó a España provocando reducción de la actividad económica y de consumo. Por ello los estudios de viabilidad de una autopista han de prever no solo un contexto, el alza, sino también las circunstancias económicas que pueden provocar la disminución del consumo.

Aparte de la mención que ya se ha efectuado sobre la no consideración de los ciclos económicos como causa que integre el riesgo imprevisible, es de resaltar que la casuística de la jurisprudencia sobre las circunstancias sobrevenidas e imprevisibles que pueden o no integrar el concepto de riesgo imprevisible es cuantiosa y conocida. Por ello, me limitaré a una breve reseña:

- Se ha considerado que debe estarse al principio de riesgo y ventura cuando el incremento de costes deriva de la aplicación de un convenio colectivo conocido por los licitadores en la fecha de presentación de sus proposiciones: STS 18 de diciembre de 2000, recurso de casación 5223/1996 (ROJ: STS 9338/2000 - ECLI:ES:TS:2000:9338).

- Se ha aceptado el restablecimiento del equilibrio económico de la concesión cuando ha habido un incremento considerable e imprevisible del número de usuarios del servicio de recogida de basuras (con el incremento consiguiente de la recaudación derivada de las tarifas satisfechas por los usuarios) superando las previsiones normales que da lugar a un desequilibrio económico en la concesión atendiendo a la justicia distributiva: STS 1 de 
julio de 1992, recurso de apelación 2701/1990 (ROJ: STS 15288/1992 ECLI:ES:TS:1992:15288).

- También se ha reputado riesgo imprevisible sobrevenido para restablecer el equilibro económico financiero de una concesión la declaración judicial fijando doctrina legal en recurso de casación en interés de la ley sobre la improcedencia de la aplicación de bonificación del 95\% de la base imponible de Impuesto de Bienes Muebles que venía aplicando una administración autonómica: STS 15 de octubre 2012, recurso de casación 1554/2011 (ROJ: STS 7003/2012 - ECLI:ES:TS:2012:7003).

\section{MEDIDAS PARA EL REEQUILIBRIO ECONÓMICO DEL CONTRATO}

Como hemos visto, de conformidad con los arts. 203 a 205, las modificaciones contractuales pueden ejecutarse y tienen un régimen jurídico diferente, cuando así se haya previsto en el pliego de cláusulas administrativas particulares y, excepcionalmente, cuando no esté prevista en el pliego de cláusulas administrativas particulares y en supuestos tasados.

Uno de los supuestos que posibilitan la modificación no prevista en los pliegos es que las modificaciones no sean sustanciales. Se concreta aquí que será sustancial aquella modificación que altere el equilibrio económico del contrato en beneficio del contratista de una manera que no estaba prevista en el contrato inicial. Esta previsión se cierra estableciendo que, en todo caso, se considerará sustancial cuando, como consecuencia de la modificación que se pretenda realizar, se introduzcan unidades de obra nuevas cuyo importe representaría más del $50 \%$ del presupuesto inicial del contrato.

Además, el art. 262.2 dispone que: «Toda modificación que afecte el equilibrio económico de la concesión se regirá por las normas generales de modificación y por lo dispuesto en el artículo 270 de la presente Ley».

La LCSP contiene una previsión sobre cuáles pueden ser las medidas a adoptar para restablecer el equilibrio económico del contrato. El art. 270.4 y, en iguales términos, el 290.5, disponen que «el restablecimiento del equilibrio económico del contrato se realizará mediante la adopción de las medidas que en cada caso procedan». Por tanto, la norma parte del principio de que habrá que adoptar las medidas que resulten necesarias y procedentes en función de las circunstancias concretas de cada caso.

No obstante, a continuación, hace una de las posibles medidas cuando dice que:

Estas medidas podrán consistir en la modificación de las tarifas establecidas por la utilización de las obras, la modificación en la retribución a abonar por la Administración concedente, la reducción del plazo concesional, y, en general, en cualquier modificación de las cláusulas de contenido económico incluidas en el 
contrato. Asimismo, en los casos previstos en la letra b) - factun principis - y en el último párrafo del apdo. 2 anterior, y siempre que la retribución del concesionario proviniere en más de un 50 por ciento de tarifas abonadas por los usuarios, podrá prorrogarse el plazo de la concesión por un período que no exceda de un 15 por ciento de su duración inicial.

El art. 290.5, para las concesiones de servicios, fija un límite añadido puesto que la ampliación del plazo del contrato por un período que no exceda de un 15 $\%$ de su duración inicial deberá respetan los límites máximos de duración previstos legalmente —cuarenta años ex art. 29.6 LCSP.

El artículo 127.2 del RSCL, cuando regula la obligación administrativa de mantener el equilibrio financiero de la concesión, indica que, para ello, la Administración «b) revisará las tarifas y subvención cuando, aun sin mediar modificaciones en el servicio, circunstancias sobrevenidas e imprevisibles determinaren, en cualquier sentido, la ruptura de la economía de la concesión».

En relación con las medidas de restablecimiento, la STS de 9 de mayo de 2014, dictada en recurso de casación 1457/2013 (ROJ: STS 2743/2014 ECLI:ES:TS:2014:2743) y en referencia al art. 248 del TRLCAP de 2000, dice que:

[...] el mecanismo legalmente previsto para el restablecimiento del equilibrio económico del contrato no consiste en el reconocimiento al concesionario de un necesario o invariable derecho a ser indemnizado en una suma económica que compense el desequilibrio producido, sino en que la Administración adopte esas específicas medidas que contempla el apartado 3 del precepto que acaba de transcribirse; unas medidas, debe añadirse, que están en línea con la naturaleza de esta especial modalidad de contrato administrativo y son acordes con la contraprestación principal reconocida al contratista (el derecho a la explotación de la obra).

Me referiré en particular a la posibilidad de prórroga de la duración del contrato como fórmula de restablecimiento del equilibrio:

10) Esta posibilidad fue admitida inicialmente en aplicación de los arts. 24 y 25 de la ley de autopistas 8/1972. Así lo hicieron las STS de 30 de abril de 2001, recurso de casación 618/1998 (ROJ: STS 3530/2001 - ECLI:ES:TS:2001:3530) y de 4 de mayo de 2005, recurso de casación 1607/2003 (ROJ: STS 2838/2005 - ECLI:ES:TS:2005:2838).

2o) Con posterioridad se ha iniciado un camino más restrictivo con base en el principio de libre concurrencia. Pueden citarse al efecto las siguientes sentencias:

STS de 25 de mayo de 2006, recurso de casación 8777/2003 (ROJ: STS 3561/2006 -ECLI:ES:TS:2006:3561), donde se argumenta que:

La pretendida compensación vía ampliación del contrato o prórroga del mismo para compensar de ese modo al contratista por la ruptura del equilibrio de los supuestos económicos que fueron considerados como básicos en la adjudi- 
cación del contrato, vulnera el principio general de la contratación pública que se refiere a la libre concurrencia, puesto que de prorrogarse o ampliarse el contrato para compensar al concesionario de los desembolsos económicos que en este caso concreto vino obligado a hacer, al modificarse el contrato en cuanto al modo de prestación del mismo, llevaría consigo que la Administración impidiese que al concluir el contrato se volviese a licitar el mismo, conculcando de ese modo el derecho de los particulares o sociedades que legítimamente aspirasen a ser adjudicatarios del servicio a la conclusión del mismo, haciendo así ilusoria la libre concurrencia en la contratación pública.

- STS de 8 de marzo de 2011, recurso de casación 4149/2008 (ROJ: STS 1259/2011 - ECLI:ES:TS:2011:1259), en la que, partiendo de la anterior, se afirma que:

No cabe duda de que las leyes pueden admitir la posibilidad de prorrogar o ampliar los plazos inicialmente pactados, como mecanismo de compensación para restablecer el equilibrio financiero alterado de las concesiones. Pero si no lo hacen, debe prevalecer el principio general de que los contratos del sector público han de atenerse a la duración en ellos convenida y que al término de ésta se ha de proceder a una nueva convocatoria pública que respete los principios de libertad de acceso a las licitaciones, publicidad y no discriminación e igualdad de trato entre los posibles candidatos. De no ser así, los contratos de gestión de los servicios públicos podrían tener carácter indefinido en la práctica, pues la sucesión de prórrogas o las ampliaciones de plazos impedirían la entrada de nuevos operadores para prestarlos, con grave detrimento del principio de concurrencia.

3o) Hoy en día, los arts. 270.3. y 290.5 LCSP son claramente restrictivos, pues solo permiten esta vía de reequilibrio, por ampliación del plazo contractual por ejercicio de la facultad del ius variandi, "cuando actuaciones de la Administración Pública concedente, por su carácter obligatorio para el concesionario, determinaran de forma directa la ruptura sustancial de la economía del contrato», exigiendo además «que la retribución del concesionario proviniere en más de un 50 por ciento de tarifas abonadas por los usuarios». Y lo que en tales casos permiten, en función de la regulación del plazo contractual del art. 29.6 LCSP, es admitir la prórroga del plazo de la concesión por un período que no exceda de un $15 \%$ de su duración inicial.

\section{PLAZO DE EJERCICIO DE LA ACCIÓN DE RECLAMACIÓN POR REEQUILIBRIO}

La STS de 22 de mayo de 2019, dictada en recurso de casación 904/2015 (ROJ: STS 1657/2019 - ECLI:ES:TS:2019:1657) resuelve que:

Y el día inicial, o díes a quo para computar el plazo de cuatro años es, conforme al artículo 25 de la LGP antes citado, «desde el día en que el derecho pudo 
ejercitarse». La actora pretende, en su escrito de 18 de febrero de 2011, reclamar perjuicios económicos desde el ańo 2002 y siguientes. Si reclama perjuicios económicos desde ese ejercicio y sucesivos, al no presentar su reclamación hasta el 2011, en dicha fecha está prescrita su acción para reclamar los perjuicios anteriores al 18 de febrero de 2007. Y así se declara en esta sentencia, pues no puede pretenderse el cumplimiento de obligaciones, cuya exigibilidad es extemporánea.

\section{EQUILIBRIO ECONÓMICO Y RIESGO OPERACIONAL EN LAS CONCESIONES}

En palabras de la propia exposición de motivos de la LCSP de 2017, la trasposición de las directivas comunitarias de contratación trae consigo que en los contratos de concesión de obras y de concesión de servicios deba haber una transferencia del riesgo operacional de la Administración al concesionario, delimitándose en el art. 14 de la ley los casos en que se considerará que el concesionario asume dicho riesgo operacional y concretando el art. 254.1 que «las obras se ejecutarán a riesgo y ventura del concesionario, quien, además, asumirá el riesgo operacional de la concesión». En la concesión de servicios el riesgo operacional pasa a ser el elemento esencial definidor del contrato, pues, por así disponerlo el art. 258.1.c) de la LCSP, los pliegos de cláusulas administrativas particulares y de prescripciones técnicas regularán la distribución de riesgos entre la Administración y el concesionario en función de las características particulares del servicio, si bien en todo caso el riesgo operacional le corresponderá al contratista.

La cuestión es ¿en qué medida la asunción del riesgo operacional afecta al equilibrio económico del contrato?, y ¿cuál es la línea que delimita el riesgo y ventura y el riesgo operacional, si es que son cosas diferentes?

Hay que partir de un hecho objetivo, que en el Real Decreto Legislativo 3/2011, de 14 de noviembre, por el que se aprueba el texto refundido de la Ley de Contratos del Sector Público, las concesiones administrativas ya se diferenciaban de los contratos administrativos por asumir el contratista-concesionario una posición de riesgo que iba más allá del principio general de riesgo y ventura. Así, el art. 246.b) disponía que es un derecho del concesionario el de «b) explotar la obra pública, asumiendo el riesgo económico de su gestión con la continuidad y en los términos establecidos en el contrato u ordenados posteriormente por el órgano de contratación»; por su parte, el art. 277 nos indicaba que: "La contratación de la gestión de los servicios públicos podrá adoptar las siguientes modalidades: a) Concesión, por la que el empresario gestionará el servicio a su propio riesgo y ventura». Por ello se admitía la existencia de un riesgo específico en las concesiones ligado a los riesgos de la gestión o explotación, como algo diferente al riesgo y ventura.

La expresión «riesgo y ventura» no impedía que se pudiera tener garantizada la inversión y los costes, sino que solo exigía una cierta incertidumbre en los beneficios. Así, en el Dictamen 1116/2015, de 10 de marzo de 2016, el Consejo 
de Estado afirmaba que «el riesgo tiene, por otra parte, de ordinario su límite en la no pérdida, esto es, en la compensación de la inversión efectuada. Lo que no puede asegurarse es un beneficio, un rendimiento positivo».

Pudiera así entenderse que el riesgo operacional no es algo tan nuevo, pues en su núcleo está, de acuerdo con el art. 14.4 de la LCSP, como lo estaba en esos riesgos específicos a que acabo de eludir, que el concesionario no tiene garantizado que, en condiciones normales de funcionamiento, vaya a recuperar las inversiones realizadas ni a cubrir los costes en que hubiera incurrido como consecuencia de la explotación de las obras que sean objeto de la concesión.

Frente a ello nos encontramos con la dicción literal del vigente art. 254.1 de la LCSP: «Las obras se ejecutarán a riesgo y ventura del concesionario, quien, además, asumirá el riesgo operacional de la concesión».

En todo caso, lo que parece claro es que según el art. 14.4 de la LCSP el concesionario no puede tener garantizado que, en condiciones normales de funcionamiento, vaya a recuperar las inversiones realizadas, ni a cubrir los costes en que hubiera incurrido, debiendo quedar realmente expuesto a las incertidumbres del mercado.

¿Cuál sería entonces la posible respuesta al interrogante apuntado más arriba?: ¿en qué medida la asunción del riesgo operacional afecta al equilibrio económico del contrato o compromete el riesgo y ventura?

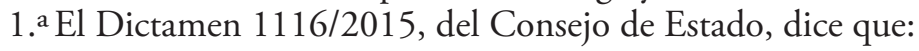

La existencia de un derecho del concesionario al equilibrio económico de la concesión en el derecho español — de tal manera que el margen de beneficio planteado en el estudio económico financiero se mantenga estable en términos económicos durante la vida del otorgamiento- choca frontalmente con el concepto de riesgo operacional. Este, como se ha dicho, existe cuando no está garantizado que el concesionario vaya a recuperar las inversiones realizadas ni a cubrir los costes, afirmando que la aplicación de la regulación de concesiones es improcedente en los casos en que se alivie al contratista de cualquier pérdida potencial garantizando unos ingresos mínimos iguales o superiores a los costes. A la vista de estas previsiones, la nueva regulación priva al concesionario del derecho al equilibrio económico en los términos tradicionales.

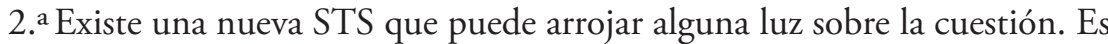
la STS de 19 de diciembre de 2019, recurso de casación 2390/2016 (ROJ: STS 4209/2019 - ECLI:ES:TS:2019:4209), que resuelve un recurso que tenía su origen en la desestimación administrativa de la reclamación de restablecimiento del equilibrio económico del «Contrato de concesión de obras públicas para la construcción y explotación de la Autovía del Pirineo A-21» que había sido articulada sobre la base de una disminución de tráficos. El origen de esa pérdida estaría en la no ejecución por la Administración del Estado - Ministerio de Fomento- de los tramos que discurrían fuera del territorio de la Comunidad Foral de Navarra - tramos aragoneses y catalanes-. 
La parte actora alegaba que no existía previsión contractual alguna que traslade a la sociedad concesionaria el riesgo de no ejecución del Corredor del Pirineo, y que ese riesgo de no ejecución no lo debe asumir el contratista porque no es una circunstancia que afecte a la explotación de la obra, sino que afecta directamente a su funcionalidad.

La sentencia dictada por la Sala territorial desestimó el recurso contencioso administrativo formulado por la entidad Autovía del Pirineo, S.A., con apoyo en la doctrina establecida en las SSTS de esta Sala de 28 de enero y 20 de abril de 2015 (RRCC 449/2012 y 54/2013), a propósito de la disminución de tráfico en autopistas de peaje como circunstancia sobrevenida que justificaría el desequilibrio de las prestaciones, y según la que formaría parte del riesgo y ventura.

Lo que vino a mantener el recurrente en casación es que la que denomina "pérdida de la funcionalidad» de la concesión, debida a la pérdida del tráfico en la parte de la concesión concernida como consecuencia de la no construcción de otros tramos del Corredor del Pirineo, no se encontraba sometida al riesgo y ventura. Parece diferenciar entre riesgo y ventura y el riesgo específico de la concesión (riesgo operacional) y para ello alegaba que su reclamación no se formula por ninguno de los riesgos que integran el riesgo operacional, es decir, excluía la pérdida de funcionalidad del riesgo operacional y consideraba que era un supuesto de factum principis, estaría integrado por la actuación de la Administración del Estado - no ejecución de tramos aragoneses y catalanes- manteniendo una interpretación amplia de la expresión legal «administración concedente», alegato este que se rechaza en casación afirmando que la expresión administración concedente en los términos que hemos visto anteriormente al analizar esta técnica de control.

Centrándonos en los riesgos, la STS, aunque no analiza directamente la relación entre riesgo y ventura y riesgo operacional, concluyó que:

[...] tal planteamiento no resulta de recibo, por cuanto dicha transferencia de riesgo — «pérdida de funcionalidad» — se traslada, como otras expresamente mencionadas, al concesionario de conformidad con la normativa que se invoca como infringida, al tratarse de un riesgo operacional -exposición a las incertidumbres del mercado - de carácter económico, y que conlleva la posibilidad de que el concesionario no recupere las inversiones realizadas ni cubra los costes que haya sufragado para la explotación de las obras adjudicadas, tratándose, pues, de un riesgo de demanda consustancial a las concesiones de infraestructuras de transporte, como la autopista de autos, tal y como, con claridad, se deducía de las cláusulas contractuales.

Y justifica la decisión final afirmando que:

Es evidente que la causa del menor tráfico en el tramo construido por la concesionaria es la no terminación del Corredor, en la parte correspondiente al Ministerio de Fomento, pero tal riesgo - con los datos que figuran en las actuacionesera un riesgo derivado de errores de apreciación de la propia recurrente, tratándose de un riesgo no imprevisible ni imprevisto, por cuanto se conocía perfectamente, por la concesionaria recurrente, tal incertidumbre antes y en el momento de la contrata- 
ción, como se deduce del Estudio de viabilidad, previo a la realización de las ofertas y conocido por todos los licitadores, del que se deduce cómo la captación de tráfico está sujeta a factores exógenos, dependientes, entre otras causas, de los cambios de política de infraestructuras que pudiera introducir el Ministerio de Fomento, posiblemente debidos a la crisis económica cuyas consecuencias se plasman en los documentos oficiales que cita la sentencia de instancia.

A modo de conclusión, siempre teórica y personal en estos casos, si de lo que se trata es de mantener la necesaria equivalencia de las prestaciones establecidas inicialmente en la concesión, parece que podría mantenerse la compatibilidad del reequilibrio económico con el riesgo operacional. Habrá que atender a las previsiones de los pliegos y contratos. La cuestión será poder diferenciar entre lo que es riesgo operacional (siempre de cuenta del concesionario) y el riesgo y ventura en sentido estricto (donde si cabe el reequilibrio por alteraciones de la ecuación económica inicial).

Ahora bien, es evidente que nunca será posible que con las técnicas del reequilibrio el concesionario quede cubierto de toda pérdida posible y que tenga asegurados unos ingresos mínimos que iguales o superen las inversiones y costes. Tal posibilidad no cabe, pues, según el art. 14.4, «el concesionario asume un riesgo operacional cuando no esté garantizado que, en condiciones normales de funcionamiento, el mismo vaya a recuperar las inversiones realizadas ni a cubrir los costes en que hubiera incurrido como consecuencia de la explotación de las obras que sean objeto de la concesión». No en vano ladoctrina del Tribunal Supremo ha establecido de modo claro y reiterado que el equilibrio económico financiero no constituye una garantía ordinaria del concesionario a modo de seguro gratuito que cubra todos sus riesgos (STS de 28 de enero de 2015, dictada en recurso de casación 449/2012, anteriormente citada).

\section{COVID Y EQUILIBRIO ECONÓMICO DEL CONTRATO}

Todo este planteamiento, como en general todo tipo de actividad, y nuestras vidas, se ha visto alterado por la causa que motivó la declaración del estado de alarma mediante Real Decreto 463/2020, de 14 de marzo.

Efectivamente, las consecuencias de tal situación determinaron la aprobación del Real Decreto Ley 8/2020, de 17 de marzo, de medidas urgentes extraordinarias para hacer frente al impacto económico y social de la COVID-19, cuyo art. 34 estableció un régimen excepcional que afectó la contratación púbica y, particularmente, al mantenimiento del equilibrio económico de los contratos de concesión de obras y de servicios, puesto que vino a reconocer que «las medidas adoptadas por el Estado, las comunidades autónomas o la Administración local para combatirlo, darán derecho al concesionario al restablecimiento del equilibrio económico del contrato mediante, según proceda en cada caso, la ampliación de su duración inicial hasta un máximo de un 15 por 100 o mediante la modifica- 
ción de las cláusulas de contenido económico incluidas en el contrato», si bien solo procederá "cuando el órgano de contratación, a instancia del contratista, hubiera apreciado la imposibilidad de ejecución del contrato como consecuencia de la situación descrita en su primer párrafo y únicamente respecto de la parte del contrato afectada por dicha imposibilidad", previsión, esta última, que fue incorporada por Real Decreto Ley 11/2020, de 31 de marzo, para permitir la excepcionalidad en los supuestos de imposibilidad total o parcial, y que también amplió la consideración de los contratos públicos afectados al hacerlo aplicable no solo a los derivados de la LCSP 2017, sino a todos los celebrados.

Por tanto, esta norma permite el reequilibrio por ejercicio del factum principis mediante dos tipos de medidas:

a) modificación de cláusulas de contenido económico, sin novedad en relación con el régimen general; $y$,

b) ampliación de la duración hasta un máximo del $15 \%$, en cuyo caso si existe una alteración del régimen general aplicable a las concesiones de servicios puesto que no se contempla el límite del art. 290.5 LCSP cuando permite la ampliación del plazo del contrato por un período que no exceda de un $15 \%$ de su duración inicial, pero «respetando los límites máximos de duración previstos legalmente», con lo que con el régimen excepcional podría superarse el plazo máximo de cuarenta años del art. 29.6 LCSP.

De esta regulación cabe analizar tres cuestiones:

1. ${ }^{\text {a }}$ Estamos ante un supuesto de factum principis.

Como hemos visto al analizar la técnica del factum principis, son las actuaciones de la Administración concedente las que posibilitan el reequilibrio, mientras que cuando proceden de Administración distinta la solución que se ofrece al contratista es la del desistimiento ligado al requisito de que el contrato resulte extraordinariamente oneroso para el contratista.

Pero en el caso de las consecuencias de la lucha contra la COVID-19, sin embargo, no estamos simplemente ante actuaciones de una administración, sino ante una realidad diferente, pues la actuación administrativa viene motivada por un elemento extraño, cual es la situación fáctica creada por la COVID-19 y, por tanto, la ruptura no sería consecuencia propia y exclusivamente del factum principis, sino que podría admitirse que, junto a ella, confluyese una situación extraordinaria de riesgo imprevisible. Estaríamos así ante la formulación del Dictamen del Consejo de Estado antes citado, número 1030/2015.

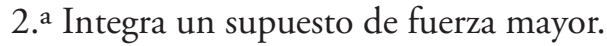

También podría plantearse si la pandemia tiene cabida en algunos de los supuestos determinantes de fuerza mayor que enumera el art. 239 LCSP, pues estamos claramente ante factores imprevisibles y anormales en el desarrollo propio de la naturaleza de las obras y ajenos a la voluntad y comportamiento del contratista, que inciden negativamente en la ejecución del contrato, suponiendo para el mismo un agravamiento sustancial de las condiciones. 
Particularmente podría analizarse si tendría cabida dentro del apartado relativo a: «Los fenómenos naturales de efectos catastróficos, como maremotos, terremotos, erupciones volcánicas, movimientos del terreno, temporales marítimos, inundaciones u otros semejantes».

Podría convenirse que nos encontramos ante una circunstancia ajena la intervención humana, pero, sin embargo, es difícil considerar la pandemia como fenómeno natural salvo que pudiera dársele cabida la expresión «u otros semejantes». En tal caso, quizá habría que enfrentarse a la doctrina jurisprudencial relativa (i) a que la enunciación de causas de fuerza mayor tiene carácter tasado y son de interpretación restrictiva (ii) a la exigencia de relación causal directa entre daño y perjuicio, pues, como ha quedado advertido al plantear la posibilidad de concurrencia del factum principis, en la ruptura del equilibrio contractual confluyen la pandemia y las medidas adoptadas por las Administraciones. En tal sentido cabe hacer nueva cita de la STS de 15 de marzo de 2005, en recurso de casación 5247/200 (ROJ: STS 1593/2005 - ECLI:ES:TS:2005:1593).

3. alcance temporal.

Las previsiones legales no alcanzan a todas las cuestiones o «secuelas» derivadas de la COVID-19, puesto que el Real Decreto Ley, dado el contenido de su disposición final décima, tiene una vigencia limitada.

Por ello, podrá plantearse el problema de qué ocurre con el equilibrio económico del contrato al finalizar este periodo temporal de vigencia.

Parece evidente que la ruptura del equilibrio puede mantenerse en el tiempo ya que la actividad económica seguirá lastrada y en situación de crisis, por lo que quizá habrá que plantearse la respuesta en ese ámbito, con lo que ello conlleva de sucesivas decisiones judiciales antes de un pronunciamiento del Tribunal Supremo y la necesidad de interpretar la legislación "ordinaria» para determinar la técnica de reequilibrio más ajustada y las medidas más adecuadas.

\section{BIBLIOGRAFÍA}

Arińo Ortiz, Gaspar (2007). Teoría del equivalente económico de los contratos administrativos. Madrid: Instituto de Estudios Administrativos.

Carrasco Perera, A. (2017). Derecho de contratos. Madrid: Thomson Reuters Aranzadi.

Fernández Farreres, G. (2020). Sistema de derecho administrativo II. Madrid: Civitas Thomson Reuters.

Gallego Córcoles, I. (2012). La ampliación del plazo concesional como fórmula del restablecimiento del equilibrio económico del contrato. Contratación Administrativa Práctica: Revista de la Contratación Administrativa y de los Contratistas, (118), 54-61.

Gamero Casado, E. y Gallego Córcoles, I. (2018). Tratados de contratos del sector público. Tomo III. Valencia: Tirant lo Blanch. 
Guerrero Manso, M. C. (coord). (2019). Observatorio de los contratos públicos. Cizur, Navarra: Aranzadi.

Hernández González, F. L. (coord.) (2016). El impacto de la crisis en la contratación pública. Madrid: Thomson Reuters-Aranzadi.

- (2018). La Nueva Concesión de Servicios. Cizur, Navarra: Editorial Aranzadi.

Huergo Lora, H. (2017). El riesgo operacional en la nueva Ley de Contratos del Sector Público. Documentación Administrativa. Disponible en: https://doi. org/10.24965/da.v0i4.10494.

Machado, S. M. (2018). Tratado de Derecho administrativo y Derecho público general. Tomo XIII: Contratos del sector público. Madrid: Boletín Oficial del Estado.

Martínez Fernández, J. M. (coord.) (2019). La gestión de los servicios públicos locales. Las Rozas: Wolters Kluwer.

Sahún Pacheco, R. (2019). La distribución de riesgos en la concesión de servicios. Critica del riesgo operacional [tesis doctoral]. Madrid: Universidad Complutense de Madrid. 
